\title{
MENAKAR MORALITAS ELIT POLITIK MELALUI KONTRAK POLITIK
}

\author{
Nasiwan \\ Jurusan PPKN Fakultas Ilmu Sosial Universitas Negeri Yogyakarta
}

\begin{abstract}
Abstrak
Before the General Election to choose the legislative members, that is beld on April 5, 2005 and President General Election, that is held on June 5 and September 20, 2004, there was a political phenomenon, which then popularly said "a political contract." The political contract was initiated by some elements of 'the civil society', which were the important components of the political power of pro-reform community.

Looking at the cultural side, the existence of the political contract in the development of Indonesian politics implied that there was a change in cognitive, affective and evaluation orientation of some of Indonesian people in their attitudes and political habits to be more rational. The emergence of the more-rational political orientation was also pusbed by the previous political experience of "being betrayed by the political elite", just like in 1999 General Election at the reform era. The chance also rose after the changes in the system of General Election that introduced the district and proportional system, and the direct president election that rose up the important of people's vote and aspiration. The changes had pushed the political elites to approach the people, fit themselves with the people's rbythm and dynamism, including the aspiration for political transparency and political accountability by willing to sign the political contract.
\end{abstract}

Kata kunci: kontrak politik, moralitas elit politik

\section{Pendahuluan}

Memasuki tahun keenam reformasi politik di Indonesia yang sudah berlangsung sejak tahun 1998, ada fenomena politik baru yang penting untuk dicermati yaitu lahirnya tuntutan dari masyarakat kepada para kandidat pejabat publik baik di legislatif maupun eksekutif untuk bersedia menandatangani "kontrak politik"1 $^{31}$ sebelum memegang jabatan publik. Tuntutan terebut lahir bersamaan

1 Istilah 'kontrak politik' dalam khazanah diskusi dan perbincangan perpolitikan di Indonesia sebelumnya tidaklah popular, istilah yang lebih dikenal ialah 'kontrak sosial', lihat Maciver, Negara Modern, Jakarta, 1988: 388-395.Isitilah kontrak politik mulai muncul kepermukaan di Indonesia setelah era reformasi politik berlangsung. Istilah kontrak politik antaralain diusulkan digunakan untuk mengatasi kebuntuan politik antara Presiden Abdurahman Wahid dengan Dewan Perwakilan Rakyat pada tahun 1999-2000. Kemudian istilah kontrak politik lebih populer lagi digunakan menjelang berlangsungnya Pemilu Legislatif 2004. Istilah kontrak politik belakangan dipakai untuk menunjukan adanya kesepakatan politik antara pihak-pihak (misalnya antara perwakilan masyarakat 
dengan berlangsungnya serangkaian peristiwa politik penting di tanah Indonesia, yakni Pemilu Legislatif pada tanggal 5 April 2004 serta Pemilu Presiden pada Bulan 5 Juli dan 20 September 2004.

Fenomena kontrak politik yang marak menjelang berlangsungnya Pemilu tahun 2004 secara umum dapat dikelompokan dalam empat kategori yaitu pertama, kontrak politik yang diajukan oleh elemen masyarakat (LSM, Mahasiswa, Budayawan, Wartawan) kepada para calon anggota legislatif menjelang dan ketika masih berlangsungnya kampanye Pemilu legislatif tahun 2004; Kedua kontrak politik antara elemen masyarakat dengan para anggota legislatif ditingkat Propinsi, Kabupaten (DPRD I dan DPRD II, DRPD Pemerintahan Kota) menjelang atau pada saat pelantikan mereka sebagai anggota legisltif; Ketiga, kontrak politik antara partai politik tertentu dengan calon Presiden pada Pemilihan Presiden Putaran II dalam hal ini adalah kontrak politik antara Partai Keadilan Sejahtera (PKS) dengan Calon Pesiden Susilo Bambang Yudoyono; Keempat kontrak politik antara para menteri Kabinet Indonesia Bersatu dengan Presiden Susilo Bambang Yudoyono sebelum memegang jabatan menteri.

Jika dicermati nampaknya ada beberapa faktor yang melatarbelakangi tumbuhnya gerakan dari masyarakat secara spontanitas untuk melakukan tuntutan kepada calon pejabata publik lebih khusus lagi pejabat politik untuk bersedia meneken kontrak politik. Beberapa faktor yang ikut mendorong kuat tumbuhnya gerakan sepihak dari rakyat untuk kontrak politik antara lain; pertama pengalaman kekecewaan rakyat yang merasa dibohongi oleh para politisi pada Pemilu 1999 yang kemudian terpilih menjadi pejabat publik tetapi tidak kunjung menepati janjijanji politiknya yang ditebar pada waktu kampanye Pemilu 1999; Kedua mulai tumbuhnya kesadaran kritis di sebagian masyarakat untuk melakukan kontrol kepada calon dan pejabat publik; Ketiga pada masyarakat Indonesia terutama di daerah-daerah perkotaan mulai tumbuh kantong-kantong elemen masyarakat yang mendukung untuk berkembangnya gagasan tentang civil society; Keempat di kalangan politisi mulai tumbuh kesadaran pentingnya untuk memperbaiki komunikasi politik dengan rakyat dalam proses mendapatkan dukungan dari rakyat; Kelima adanya perubahan sistem Pemilu Presiden secara langsung dan Pemilu anggota Legislatif dengan sistem Proposional terbuka dan Distrik berwakil banyak, pada satu sisi mendorong posisi konstituen menjadi sedemikian penting bagi calon pejabat publik dan pada sisi yang lain juga telah mendorong terjadinya perubahan strategi para politisi untuk bisa meraih dukungan dan keprcayaan rakyat.

dengan calon anggota legislative, antara partai dengan calon presiden, antara Presiden Susilo Bambang Yudoyono dengan para calon menteri Kabinet Indonesia Bersatu) yang mengadakan kontrak atau perjanjian tentang hal-hal yang berkaitan dengan masalah politik, misalnya masalah pemerintahan yang bebas $\mathrm{KKN}$, perlindungan hak-hak rakyat, masalah transparansi Anggaran lembaga publik dll, lihat Kompas tanggal 23 Oktober 2004 hal 1. 
Sehubungan dengan munculnya fenomena gerakan rakyat untuk menuntut dilakukan kontrak politik menurut hemat penulis menarik untuk dipertanyakan lebih mendalam bagaimanakah kontribusi kontrak politik tersebut bagi hadirnya kehidupan politik yang lebih demoktatis dalam rangka konsolidasi demokrasi? Apakah kontrak politik efektif untuk menekan para pejabat publik agar tidak melakukan penyimpangan? Bagaimanakah prospek aktivitas kontrak politik tersebut? Gerakan kontrak politik yang dilakukan oleh masyarakat tersebut apakah lebih merupakan gerakan moral ataukah akan berubah menjadi bagian dari tradisi dan budaya politik Indonesia? Mengapa dalam kontrak politik tersebut tidak semua elit politik memberikan dukungan, khususnya elit politik dari partai-partai besar?

\section{Kontrak politik antara Kekecewaan dan Moralitas Politik}

Bagaimanakah mendudukkan dan membaca fenomena kontrak politik? Apakah kemunculan kontrak politik menjelang Pemilu 2004 itu pertanda adanya peluang untuk perbaikan bagi kehidupan politik yang demokratis sekaligus mendasarkan kehidupan politik tersebut pada suatu etika dan moraliltas politik publik dalam mengelola negara mengingat adanya tuntutan kuat dari masyarakat kepada calon pejabat publik? Ataukah hal tersebut sebagai pertanda bahwa publik mempunyai keberanian untuk mempertanyakan disertai kesangsian akan keseriusan pejabat publik dalam mengurus dan mengelola persoalan publik? Ataukah pertanda munculnya ketidakpercayaan rakyat kepada pejabat publik?

Mencermati sikap politik rakyat Indonesia menghadapi peristiwa politik penting Pemilu 2004, rakyat nampaknya masih memiliki ruang toleran yang cukup untuk memberikan kesempatan kepada candidat pejabaat publik 'para politisi' untuk menduduki jabatan publik tetapi kali ini dengan disertai kontrak politik, yang sewaktu-waktu pada saatnya dapat ditagih jika pejabat publik tersebut dalam pelaksanaannya tidak bisa menunaikan dengan amanah janji yang telah diucapkan dan dituliskan dalam bentuk kontrak politik. Walaupun harus segera ditambahkan bahwa pada sebahagian masyarakat juga sudah mulai muncul sikap apatis dan tidak percaya kepada pejabat publik dari para politisi Indonesia karena seringnya ingkar janji di masa lalu. Bahkan ketidakpercayaan tersebut tidak hanya terbatas pada aktor politik sja tetapi juga sampai pada sistem politik dan perangkat yang menopang sisem tersebut. Gejala awalnya dapat dibaca pada semakin banyaknya warga negara Indonesia yang memiliki hak pilih tetapi tidak menggunakan haknya untuk memilih baik pada Pemilu Legislatif maupun pada Pemilu Presiden. (angkanya mencapai 25 juta Jiwa yang tidak menggunakan hak pilihnya pada Pemilu Presiden 2004). (Kompas dan Tempo, Bulan Oktober 2004)

Gerakan kontrak politik karena belum menjadi bagian dari ketentuan aturan main yang disepakati dalam kehidupan politik resmi maka pelanggaran dari ketentuan dalam kontrak politik, nampaknya tidak bisa diikuti oleh sanksi yang bersifat pidana. Sanksinya nampaknya lebih pada sanksi yang bersifat moral dan hukuman sosial pada para aktor dan institusi politik tempat para aktor politik 
berinduk. Hal yang demikian nampaknya juga cukup disadari oleh para penggerak dan pegiat gerakan kontrak politik. Namun demikian gerakan tersebut sebagai suatu ikhtiat untuk mengubah adanya stagnasi kehidupan politik menuju kearah yang lebih dinamis adalah merupakan suatu kemajuan dalam kehidupan dan budaya politik di Indonesia, perlu mendapatkan apresiasi dan support secara akademis.

Jika dipertanyakan bagaimanakah kontribusinya pada perubahan politik pada perubahan kehidupan politik yang bermoral dan beretika publik dalam kerangka konsolidasi demokrasi? Pertanyaan ini nampaknya belum bisa mendapatkan jawaban yang memuaskan. Masih harus menunggu bukti-bukti yang lebih meyakinkan lagi dalam pergumulan politik real di lapangan.

Sekalipun belum ada suatu rumusan yang jelas tentang pengaruh gerakan kontrak politik pada proses konsolidasi demokrasi di Indonesia, satu hal yang dapat dipastikan ialah bahwa melalui gerakan kontak politik terebut masyarakat Indonesia telah mengirimkan pesan dan aspirasi kepada bangsa Indonesia secara umum dan para calon pejabat publik pada khususnya bahwa menjadi pejabat publik khususnya untuk jabatan politik perlu setia kepada nilai-nilai tertentu yang melalui gerakan kontrak politik tersebut dicoba untuk ditawarkan. Nilai-nilai yang dimintakan oleh para pendukung gerakan kontrak politik untuk disetujui oleh para calon pejabat publik antara lain:

1.Pejabat publik (para politisi) dituntut untuk memiliki komitmen yang kuat dalam membela dan memperjuangkan nasib rakyat Indonesia pada umumnya dan nasib konstituen pada khususnya.

2.Tuntutan kepada para pejabat publik untuk menghadirkan suatu proses politik dan pemerintahan yang transparan dan akuntable.

3.Tuntutan untuk menghadirkan suatu pemerintahan yang bersih dari korupsi, kolusi dan nepotisme, menuju pada terwujudnya good governance.

4.Tuntutan untuk menghilangkan adanya kecenderungan terjadinya elitisme politik, feodalisme politik dalam kehidupan politik di Indonesia.

5.Tuntutan untuk memperhatikan dan menjaga nilai-nilai lokal yang merupakan bagian dari kekayaan budaya nasional.

6. Tuntutan untuk segera mengentaskan kemiskinan khususnya masyarakat di daerah sesuai dengan era otonomi daerah.

7. Tuntutan untuk menghadirkan suatu kehidupan negara yang berdaulat tidak berada dalam bayang-bayang kekuasaan negara lain.

8. Tuntutan untuk menegakan supremasi sipil dan hdirnya militer yang profesional dalam menjaga keutuhan negara Kesatuan Republik Indonesia.

9. Tuntutan untuk menciptakan suatu kehidupan masyarakat Indonesia yang lebih bermoral dalam segala aspek kehidupannya. (Diolah dari berbagai 
sumber pemberitaan mas media yang terbit pada bulan menjelang dilaksanakannya Pemilu 2004 yang terkait dengan masalah kontrak politik). ${ }^{2}$

Nilai-nilai penting yang sering muncul dalam berbagai dekalrasi dan aksi masyarakat yang mendukung dibuatnya suatu kontrak politik antara calon pejabat publik dengan rakyat, sebagaimana dikemukakan di atas, adalah nilai-nilai moral yang sangat potensial untuk mendukung dan terwujudnya konsensus nasional tentang moralitas politik nasional dalam kehidupan politik. Sekalipun ketika nilainilai tersebut ditawarkan melalui berbagai aksi oleh masyarakat masih belum mendapatkan dukungan secara memuaskan dari kekuatan-kekuatan politik yang hidup di Indonesia, namun getaran dan vibrasi gelombang tuntuan tersebut terus bergema dan tidak bisa dibendung lagi. Dengan suka maupun terpaksa kekuatankekuatan politik yang ada pada akhirnya harus memberikan respon poisitif kepada gerakan kontrak politik, jika mereka tidak ingin ditinggalkan oleh rakyat pendukungnya.

Dengan rumusan lain kiranya dapat dinyatakan bahwa gerakan untuk melakukan kontrak politik pada para pejabat publik di Indonesia memiliki prospek yang baik. Prospek yang baik ini muncul karena adanya berbagai faktor yang mendukung. Faktor-faktor tersebut antara lain:

1.Mulai tumbuh dan membesarnya kekuatan civil society di Indonesia yang mendorong keberanian masyarakat untuk menekan dan mengontrol kinerja pejabat publik.

2. Adanya perubahan Sistem Pemilu di Indonesia, yaitu Pemilu secara langsung dalam Pemelihan Presiden, Gubernur, Bupati, Wali Kota, yang mengharuskan para pejabat publik harus dekat dengan rakyat serta harus mendengar dengan sungguh-sungguh kemauan dan aspirasi rakyat.

3.Lahirnya pers yang relatif mandiri dan bebas, yang memberikan dukungan pada gerakan kontrak politik melalui pemberitaan baik melalui media cetak maupun media eletronik.

Dilihat dari sisi kebudayaan politik, kiranya dapat dibaca bahwa munculnya fenomena kontrak politik dalam kehidupan politik di Indonesia menjelang berlangsungnya Pemilu 2004 serta paska Pemilu 2004, menunjukan bahwa orientasi politik, sikap dan preferensi masyarakat Indonesia sebagaiannya sedang mengalami perubahan ke erah budaya politik yang partisipatif. Keberanian elemen-lemen dari perwakilan rakyat untuk menuntut adanya kontrak politik dengan calon pejabat publik dan para politisi yang akan mengisi jabatan -jabatan publik adalah menunjukan adanya pergesaran orientasi, pemahaman politik masyarakat Indonesia bahwa masalah politik dalam kehidupan demokrasi adalah merupakan persoalan yang rasional, persoalan rakyat kebanyakan, bukan hanya monopoli dan milik istimewa para elit politik saja yang berhak mengelola. 
Keberanian elemen-elemen rakyat bersentuhan dengan masalah politik yang pada era sebelumnya setengah dikeramatkan dapat dibaca telah terjadi perubahan orientasi dan sikap politik ke arah yang lebih rasional serta evaluatif. ${ }^{3}$

Sekalipun harus segera dicatat bahwa kekuatan-kekuatan politik ataupun aktoraktor politik yang pro getakan kontrak politik serta menjadi pelopor gerakan kontrak politik, dalam kehidupan politik real belum mendapatkan dukungan yang mayoritas dari masyarakat Indonesia. Hal tersebut antara lain dapat dibaca pada adanya kenyataan bahwa partai-partai politik serta tokoh-tokoh politik yang memiliki gagasan jelas dan terencana tentang kontrak politik dalam Pemilu tahun 2004 di Indonesia masih dikalahkan perolehan dukungannya oleh partai politik ataupun aktor politik yang tidak memiliki gagasan terlalu jelas tentang kontrak politik tetapi mereka memiliki ikatan primordial dengan para pendukung. ${ }^{4}$

Dengan demikian dari fenomena adanya kontrak politik di Indonesia menjelang terjadinya sirkulasi posisi-posisi penting pada jabatan publik dapt dibaca dari dua perspektif; yang pertama dilihat dari sisi rakyat kiranya dapat dinyatakan bahwa lahirnya tuntutan adanya kontrak politik adalah berkaitan dengan adanya ketidakpuasaaan dan kekecewaaan rakyat baik pada masa sebelum reformasi ataupun pada masa seteelah reformasi politik tahun 1988, pada moralitas politik para pejabat publik yang terdiri dari para poltisi yang sering ingkar janji serta dipertanyakan komitmennya untuk memperjuangkan nasib rakyat. Namun pada sisi yang lain juga menunjukan telah mulai tumbuhnya kesadaran dikalangan elit politik misalnya pada Presiden Susilo Bambang Yudoyono untuk menciptakan mekanisme etika politik 'code of conduct' dalam proses penyelenggaraan pemerintahan di Indoensia. Hal tersebut adalah merupakan perkembangan baru dalam budaya politik di Indonesia yang belum pernah terjadi pada masa-masa sebelumnya. Pada masa-masa sebelumnya nengadakan aktivitas semacam kontrak politik dipandang sebagai sesuatu aktivitas politik yang tidak sesuai dengan tradisi dan budaya bangsa Indonesia yang dibalut dengan selubung nilai-nilai feodalisme.

Kembali ke pertanyaan awal tulisan ini, apakah kontrak politik memiliki kontribusi pada proses konsolidasi demoktasi di Idonesia? Dari pemaparan di atas kiranya dapat dinyatakan bahwa dalam derajat tertentu gerakan kontrak politik dilihat dari sisi dukungan rakyat untuk mempercayai perubahan politik melalui mekanisme demokrasi tidak melalui jalan kekerasan maka gerakan kontrak politik telah memberikan kontribusi untuk berejalannya konsolidasi demokrasi di Indonesia. Karena diantra ciri terpenting berjalanya konsolidasi demokrasi adalah disepakatinya mekanisme demokrasi oleh lemen-elemen masyarakat ataupun para

\footnotetext{
${ }^{3}$ Lihat, Gabriel A. Almond dan Sydney Verba, Budaya Politik Tingkah laku Politik dan Demokrasi di Lima Negara, Jakarta, Bina Aksara, 1984:113-16.

${ }^{4}$ Lihat, Titok Haryanto dan Joko Purnomo, Uji Komitmen melalui Kontrak Politik, Makalah Seminar Internasional ke-5 Percik 14.17 Juli 2004, Salatiga.
} 
aktor politik untuk menyelesaikan segala persoalan politik yang dihadapi bersama oleh masyarakat, dengan diterimanya prinsip the onley game in town. ${ }^{5}$

Salah satu isu yang menonjol dalam kontrak politik adalah isu tentang pencegahan penyalahgunaan kekuasaan bagi pejabat publik ataupun pejabat politik. Penyalahgunaan kekuasaan (obousses of Power) itulah yang dalam praktek politik sangat mudah menghadirkan berbagai macam KKN di Indonesia selama bertahun-tahun. Jika gerakan untuk mengadakan kontrak politik dikaitkan dengan isu pemberantasan dan pencegahan penyalahagunaan kekuasaan di Indonesia kiranya dapat dinyatakan bahwa gerakan tersebut cukup memiliki pengaruh yang signifikan.

Pengaruh yang signifikan tersebut antara lain dapat dibaca dari cepatnya gerakan untuk mengadakan kontrak politik menjalar secara massif hampir di seluruh Indonesia. Gerakan untuk melakukan kontrak politik tesebut tidak hanya terjadi di Ibu Kota Jakarta ataupun di daerah pulau Jawa tetapi juga sampai di daerah-daerah di Luar pulau Jawa. Menginngat luasnya penyebaran gagasan untuk mengadakan kontrak politik maka dapt dinyatakan bahwa gerakan ini memiliki potensi yang sangat besar untuk memberantas terjadinya penyalahgunaan kekuasaan oleh para pejabat publik (pejabat politik) di Indonesia. Peran media massa sebagai salah satu pilar dari demokrasi sangat vital dalam rangka mempertahankan ritme dan tetap menggelorakan semangat untuk mengawasi pejaat publik.

\section{Kontrak politik antara Partai Politik dan Kandidat Presiden}

Berkaitan dengan masalah perkembangan kontrak politik di Indonesia, suatu hal yang menarik diperhatikan adalah adanya kontrak politik antara parpol tertentu dengan calon Presiden. Adanya dukungan yang bersyarat dari parpol tertentu dengan calon presiden yang diadakan menjelang berlangsungnya Pemilihan presiden adalah merupakan hal baru yang terjadi dalam tradisi perpolitikan di Indonesia. Peristiwa kontrak politik yang terjadi antara Partai Keadilan Sejahtera (PKS) dengan Calon Prsiden Susilo Bambang Yudoyono, menjelang berlangsungnya pemilihan presiden Putaran Kedua menarik untuk dicermati dan didiskusikan.

Kontrak politik atau nota kesepahaman antara Partai Keadilan Sejahtera dengan Cndidat Presiden Susilo Bambangn Yudoyono-Yusuf Kala diumumkan di Kantor DPP PKS Hari Kamis 26 Agustus 2004. Point-point dari kontrak politik tersebut berisi:

1.Konsisten melakukan perubahan untuk membangun pemerintahan yang bersih, peduli, dan profesional. Hal itu antara lain dibuktikan dengan keteladanan dan kesiapan memberhentikan anggota kabinet yang melakukan

\footnotetext{
${ }^{5}$ Lihat Mochtar Mas'oed, Makalah Semianr Nasional, Konsolidasi Demokrasi Indonesia dalam Perspektif Komparatif, Yogyakarta, UGM 119 September 200:7.
} 
korupsi, tidak mengulangi pengelolaan negara yang sebelumnya dan tidak menjadikan kekuasaan untuk menzalimi umat dan bangsa Indonesia.

2.Mempertahankan kedaulatan Negara Kesatuan Republik Indonesia di tengah percaturan dan pergaulan dunia internasional.

3.Melanjutkan proses demoktatisasi dan reformasi dalam rangka terbentuknya masyarakat madani, mengedepankan supremasi sipil, dan tidak menghadirkan pemerintahan militeristik dan atau police state.

4.Meningkatkan moralitas bangsa, kualitas masyarakat dan kesejahteraan masyarakat dan mengedepankan penegakan hukum serta penghormatan terhadap hak asasi manusia.

5.Mendukung upaya perjuangan bangsa Palestina dalam mencapai kemerdekaan dan tidak menjalin hubungan diplomatik dengan Israel.

Dijelaskan oleh Presiden Partai Keadilan Sejahtera Dr. Hidayat Nur Wahid, bahwa keputusan PKS mengadakan nota kesepahaman untuk mendukung pasangan candidat Presiden Susilo Bambang Yudoyono- Yusuf Kalla adalah bersifat mengikat kepada seluruh pengurus dan kader PKS, serta menjadi pedoman bagi simpatisan dan konstituen yang bertekad untuk melakukan perubahan bersama PKS. Dukungan penuh PKS didasarkan pada nota kesepahaman dengan Yudoyono-Kalla untuk menjalin kebersamaan dalam melaksanakan perubahan menuju Indonesia Madani yang adil, aman, dan sejahtera. ${ }^{6}$

Fenomena dukungan dari partai politik tertentu kepada candidat Presiden dengan melalui kontrak politik dalam sejarah pemilihan presiden sertasejarah politik Indonesia adalah merupakan suatu fenomena yang baru. Peristiwa tersebut dapat dibaca bahwa dukungan dari partai politik kepada candidat presiden dalam Pemilihan Presiden di Indonesia tahun 2004 merujuk pada prinsip-prinsip nilai tertentu yang disepakati oleh kedua belah pihak. Dari sisi etika dan moralitas politik dukungan ataupun koalisi antara berbagai kekuatan politik yang merujuk pada adanya kesepakatan dan kedekatan nilai-nilai yang diperjuangkan (platforme) adalah merupakan suatu hal yang imperatif, yang seharusnya dijunjung tinggi oleh para politisi. Hal tersebut akan lebih menjamin adanya kerja sama dan koalisi yang stabil. Dan sebaliknya prelu dihindari suatu dukungan atau koalisi antara brbagai kekuatan politik yang lebih didasarkan kepada kepentingan politik praktis dan taktis, atau yang sering disebut dengan politik dagang sapi. Mengapa demikian? Karena acapkali dukungan yang diberikan dalam politik dagang sapi mengabaikan nilai-nilai yang menjadi rujukan bagi garis perjuangan partai dan berarti pula melakukan pengkhianatan pada para pendukung (konstituen) partai yang telah memberikan dukungan pada partai tersebut. Konstituen partai politik sering kali dikhianati oleh elit partai, karena elit partai tidak menepati apa yang dilampanyekan

${ }^{6}$ Lihat Kompas, tanggal 27 Agustus 2004 hal 1 dan 11. 
dalam Pemilu., lantaran elit partai tersebut mengejar kedudukan politik dengan menggadaikan idealisme partai.

Dengan demikian kiranya dapat dinyatakan bahwa fenomena adanya kontrak politik antara partai politik dengan candidat presiden ataupun calon pejabat publik dari sisi moralitas politik dapat dibaca sebagai suatu perkembangan yang positif dalam dinamika perpolitikan di Indonesia. Kehidupan politik Indonesia dengan kontrak politik tersebut menjadi berpeluang berkembang kearah kehidupan politik yang rasional, transparan dan acountable.

\section{Kontrak politik antara Calon Menteri KIB dengan Presiden SBY}

Fakta adanya kontrak politik antara para calon menteri Kabinet Indonesia Bersatu (KIB) dengan Presiden Susilo Bambang Yudoyono (SBY) yang berlangsung sebelum dilantik menjadi pejabat publik pada masing-masing pos kementerian yang tesedia adalah merupakan suatu fenomena politik baru. Term kontrak politik belum pernah ada dalam kebinet-kebinet sebelumnya baik pada masa Orde Lama, Orede Baru maupun Orde Reformasi sebelum masa Pemerintahan di bawah Presiden SBY.

Fenomena baru tersebut menarik untuk dicermati dari sisi pertumbuhan kesadaran moralitas publik para pejabat dan candidat pejabat yang akan memangku jabatan publik. Pertanyaan yang layak untuk diajukan apakah lahimya kontrak politik tersebut adalah termasuk dalam kategori perbuatan politik yang dipandang bermoral untuk konteks bangsa Indonesia ataukah perbuatan tersebut sudah keluar dari tradisi dan budaya politik bangsa Indonesia, sebagai bangsa yang menghargai nilai-nilai kesantunan, basa-basi, tidak begitu suka pada hal-hal yang bersifat transparan, terbuka dan keterus terangan.

Mencermati tanggapan publik atas lahirnya kontrak politik tersebut nampaknya sebagain besar publik Indonesia menanggapi dengan baik dan positif atas gagasan baru perlunya kontrak politik bagi para pejabat publik dalam rangka menjaga etika berpolitik serta untuk menjaga kestabilan jalanya roda pemerintahan. Memang jika dicermati isi dari kontrak politik bagi para pejabat publik dalam hal ini adalah para menteri itu berisikan point-point yang sangat mendukung lahirnya suatu pemerintahan yang akuntable dan transparan sehingga bisa mendukung untuk menghindarkan pemerintahan dari penyakit $\mathrm{KKN}$ yang menjadi inti dari tuntutan rakyat dalam menggulirkan reformasi politik sejak tahun 1998.

Point-point penting kontak politik calon menteri dengan Presiden SBY:

1.Setiap anggota kabinet siap bekerja keras mengutamakan kepentingan pemerintah dan negara di atas kepentingan partai, golongan atau pribadi.

2. Mencurahkan waktu, pikiran, dan tenaga untuk tugas yang diembannya.

3. Tidak akan melakukan korupsi dan siap diperiksa harta kekayaannya dan apabila secara hukum terbukti melakukan korupsi atau penyelewengan, siap untuk mundur. 
4.Siap dieavaluasi oleh presiden kinerja dan prestasinya. ${ }^{7}$

Jika tradisi ataupun konvensi politik yang bernama kontrak politik ini terus dapat dipertahankan dalam kehidupan politik Indonesia baik antara partai politik yang akan berkoalisi dengan partai lain ataupun akan berkoalisi dengan candidat presiden tertentu serta antara candidat menteri dengan presiden terpilih, menurut hemat penulis akan mem berikan energi yang besar bagi tumbuhnya kehidupan politik di Indonesia yang berpijak pada moralitas politik. Yakni prinsip-prinsip nilai untuk menepati komitmen dengan rakyat serta komitmen diantara para politisi. Lahirnya saling percaya atau situasi adanya 'Trust',adalah merupakan modal yang sangat penting untuk menghadirkan suatu kehidupan politik yang beradab, suatu kehidupan politik yang memancarkan nilai-nilai kehangatan nilai kemanusian, kehidupan politik yang mampu memprkuat nilai-nilai adi luhung, seperti kejujuran, kesetian, komitmen, terbuka, menjunjung tinggi aturan main, empati dan nilai-nilai lain yang sejenis.

\section{Penutup}

Pada penghujung tulisan ini kiranya dapat ditarik pemahaman bahwa lahirnya fenomena politik yang kemudian populer disebut dengan kontrak politik menjelang berlangsungnya Pemilu tahun 2004 adalah merupakan suatu perkembangan politik yang positif. Perkembangan orientasi politik masyarakat Indonesia kearah lebih rasional yang memiliki peluang kontribusi bagi penguatan untuk lahirnya kehidupan politik yang berpijak dan menghargai moralitas politik. Dimasa depan kontrak politik memiliki prospek untuk terus dipergunakan dan menjadi model bagi lahimya suatu aktivitas politik yang beradab yang berangkat dari adanya saling percaya 'trust'.

Sekalipun pada awalnya masih ada kekuatan-kekuatan poltik yang belum sepenuhnya setuju dengan model kontrak politik, dengan alibi politik yang beraroma konservatif, perkembangan menunjukan bahwa model kontrak politik ini semakin hari semakin mendapatkan dukungan yang semakin luas baik dari publik Indonesia maupun dari elit politik Indonesia, termasuk pasangan Presiden Susilo Bambang Yudoyono - Yusuf kalla dari Kabinet Indonesia Bersatu.

${ }^{7}$ Lihat, Kompas, 23 Oktober 2004. 